\title{
French government proposes big science-spending boost
}

\section{President Emmanuel Macron's 2018 draft budget would raise research funds by 6\%. \\ Barbara Casassus}

29 September 2017

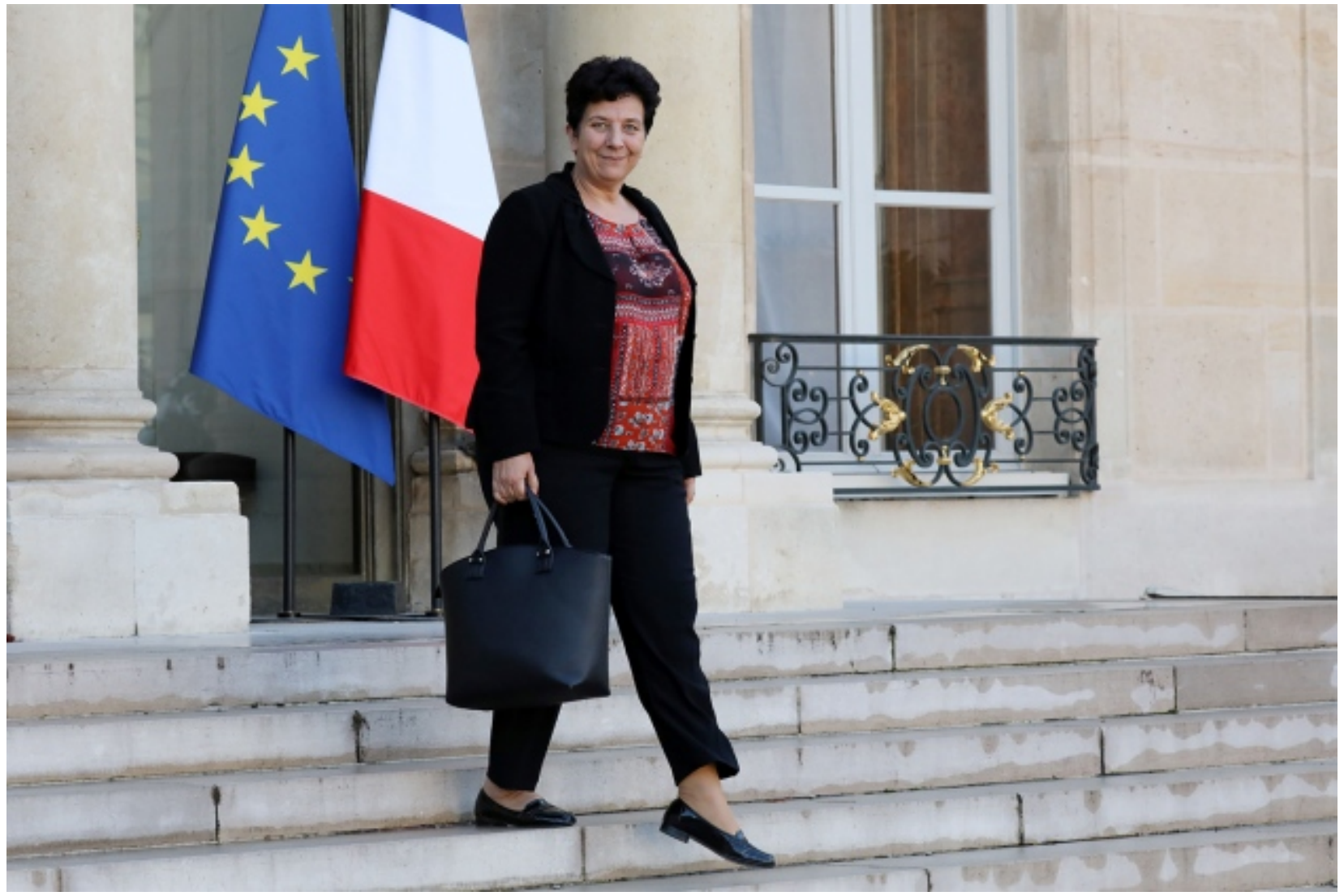

Ludovic Marin/AFP/Getty Images

Frédérique Vidal, France's higher education, research and innovation minister, said the budget would give 'fresh oxygen' to the country's research.

French research funding is set for a heartening increase in the country's first budget under President Emmanuel Macron, if draft 2018 plans released on 27 September are voted into law.

The research portfolio of France's ministry of higher education, research and innovation would rise by more than $6 \%$, to $€ 8.4$ billion (US $\$ 9.9$ billion) in 2018 . And on top of that, a giant economic-recovery 
plan unveiled on 25 September by Prime Minister Edouard Philippe should divert an extra €2.4 billion to research over the next five years.

The cash injection will lead to a "small revolution", said Frédérique Vidal, the country's minister for higher education, research and innovation at a press conference the day after the budget release. In particular, Vidal said that France's public laboratories stand to gain money after years of cuts. "We all know we have come to the end of a movement where laboratories' allocations have been trimmed, year after year. With the 2018 budget, we are reversing the trend and are starting to give fresh oxygen to our research," she said.

Scientists who have long campaigned for more funding praised the proposals. "It is a signal that President Macron and the government have understood the long-term consequences of the funding crisis that has hit universities and research agencies for years," says Patrick Lemaire, a biologist at the University of Montpellier and founder of the Related stories

- President of troubled French funding agency resigns

- Climate scientists flock to France's call

- Scientists relieved by Emmanuel Macron's French election victory

\section{Related stories}

- President of troubled French funding agency resigns

- Climate scientists flock to France's call

- Scientists relieved by Emmanuel Macron's French election victory researcher-led campaign group Sciences en Marche.

For Bernard Meunier, a chemist and a past president of the French Academy of Sciences, the most positive point of the budget was that Vidal seemed to recognize the poor state of French labs' finances. “There couldn't be any further cut in their funding, because there is practically nothing left. The minister is aware there is a problem, whereas her predecessors said there wasn't," he says.

In the draft proposal, the French National Research Agency (ANR), which funds individual projects on a competitive basis, would see its budget rise by $5 \%$, to $€ 706$ million - although its funding levels are still slightly lower than they were in 2012, and it still has no head after former president and chief executive Michael Matlosz resigned in July. Competition for grant funding remains fierce at the ANR, where only around $12 \%$ of grant applications are successful, and Lemaire doubts that the extra money will do much to improve that. 
The funding boost is welcome, but not sufficient on its own to transform the agency, says Meunier. "We need the ANR to be restructured to permit more blue-skies funding and simpler grant-application procedures," he says.

There would be a smaller increase for the country's public-research bodies — including the basicresearch agency CNRS and the biomedical agency INSERM — which give out grants and run their own laboratories, many of them jointly with universities. These agencies see their collective spending rise by just over $1 \%$, to $€ 5.94$ billion. Some of the money will be used for Macron's Make Our Planet Great Again campaign, which aims to attract foreign climate scientists to France.

This year's budget is the first since Vidal, a biochemist who was president of the University of Nice Sophia Antipolis from 2012 to 2017, was appointed to the research ministry. In a sign that France's government is taking the post more seriously, Vidal's role was also made more senior: she reports directly to the prime minister, whereas her predecessor, Thierry Mandon, reported to a minister for education.

The proposed increases are all the more welcome because the European Commission is pressuring France to rein in its deficit. This July, around €184 million was trimmed from the ministry's 2017 budget for research, as part of a series of public-spending cuts.

France's controversial system of tax credits for companies that conduct research will remain in place, economy and finance minister Bruno Le Maire told reporters. The system, which costs the state up to $€ 6$ billion a year in tax revenues, has come under fire for alleged abuses: critics say companies use it to reduce their tax bill, rather than to increase their research spending. But Le Maire said he would simplify the system to make it easier for smaller companies to apply for credits, although he did not give details.

Macron, meanwhile, has urged the European Union to pay more attention to research. In a 26 September speech, he argued that the EU should create an agency to accelerate the commercial applications of basic science, with the idea of spurring innovation in fields such as artificial intelligence.

Nature doi:10.1038/nature.2017.22733 